可視化情報 Vol. 11 Suppl. No.1（1991年7月）

\title{
33 回流水慒を用いた天文台ドームの形態们閔する换傠
}

\author{
航技研 \\ 進藤重美只坂田公夫 \\ 国立天文台 安藤裕康、宮下晦彦
}

\begin{abstract}
Some Considerations on the Outer Shape of Telescope Enclosure
\end{abstract} with Circulating Water Channel Tests

Shigemi Shindo*, Kimio Sakata*

Hiroyasu Ando**, Akihiko Miyashita**

\begin{abstract}
Studies of seeing conditions inside telescope domes indicate a need to provice substantial air ventilation to prevent image degradation due to thermal variation of the air within the dome that means fluid-dynamic designing is necessary for choosing dome style. Althoughthe traditional enclosure is a cylinder topped by a hemispherical dome, alternative style such as flat-loof or tapezoidal topped cylinder could be considered from view point of fluid dynamic feature. Significant flushing flow without thermal ground boundary layer coming into the dome is the subjects to investigate. Water channel tests were made using 3 Types of 1:500 scale enclosure models with flow visualization methods. Dye injection method was mainly used and some quantitative measurements were done. Among the models, the cylindrer with near-flat roofs appear to be superior. And the sidewalls on either side of the telescope were found to be beneficial for flushing the flow.
\end{abstract}

1. 緒言

天文観測用のドームはこれまで半球状の特徽ある屋根を持つ円柱形状であるのが普通であった。 しかし、我が国が標高4，200mのハワイ島マウナケア山頂の国際観测所に建設を計画している直径 $8 \mathrm{~m}$ の光学赤外線反射望遠鏡(1)では、その分解能を世界一の 0.2 秒程度まで高めることを目標に しており、これを実現する為に光学系の設計等の様々な努力が重ねているが、ドーム内の滞留空 気の温度分布或いは反射鏡面上の温度境界層による像の摇らぎが問題となる程の临しい条件であ る。そこで、マウナケア山頂に定常的に吹く、温度 $-5^{\circ} \mathrm{C}$ から $10^{\circ} \mathrm{C}$ 、風速 $9 \mathrm{~m} / \mathrm{sec}$ の安定した貿易 風を利用してドーム内を温度一定の新鮮な外気でフラッシング（洗い流し）して、空気による摇 らぎを無くす方法が期待される。このため、ドーム外形状から設計を検討する必要が生じた。従 ってドームの外形及び内部流を支配する換気丹、ルーバ等の配置など流体力学的な設計が必要之 なり、これらに関する基礎資料を得るため、数種の小型の模型を製作し、航空宇宙技術研究所の 小型回流水槽を用いて流れの可視化を含む基礎的な試験を行った。各ドームの特性は、（1）ドー ム内への外気流の流入が円滑であり、風向きに鈍感であること、(2)鏡面上に一定の余り速くな

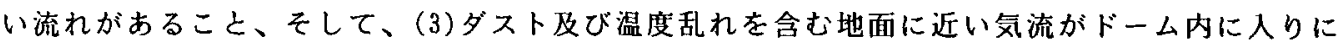
くいこと、等について評価することとし、水素気泡法及び色素流眽法を用いた流れの可視化によ つて流体力学的な特性を解析した。(2)

\section{2. 模型及び装置}

図 1 は実験に供したドーム模型の構造である。候補の形状に半球形、台形及び円筒形の三種を 選び、水槽の大きさから実物の $1 / 500$ スケール(ドーム外径 $80 \mathrm{~mm})$ とした。望遠鏡の光路を確保す た外部流線を制御するための整流板をスリットの下部に設けた。半球形は従来からの形状であり、 るため、スリットを主たる流路と考え流入速度を隇ずるための金網あるいは多孔板をもうけ、ま * National Aerospace Laboratory, Jindaiji-higashimachi 7-44-1, Chofu, Tokyo 182, JAPAN ** National Astronomical Observatory, Osawa 2-21-1, Mitaka, Tokyo 181, JAPAN 

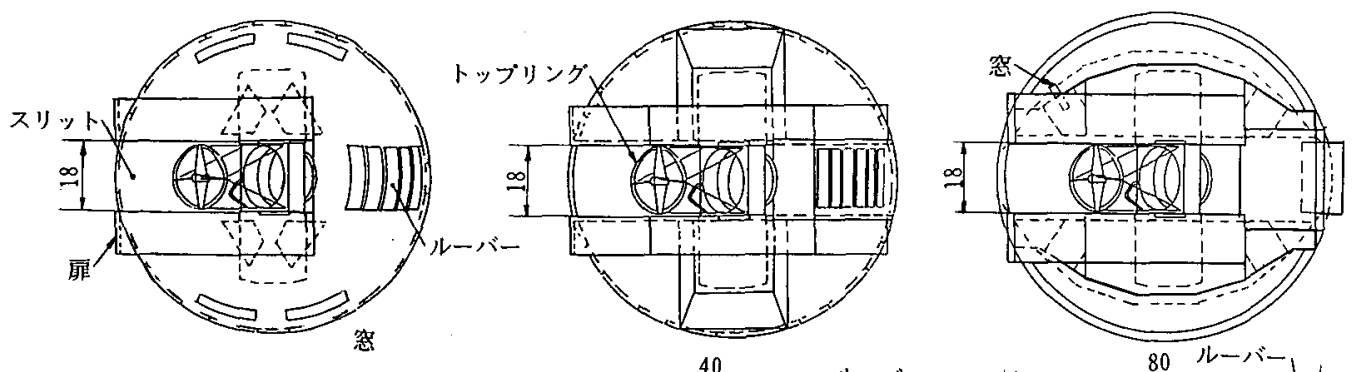

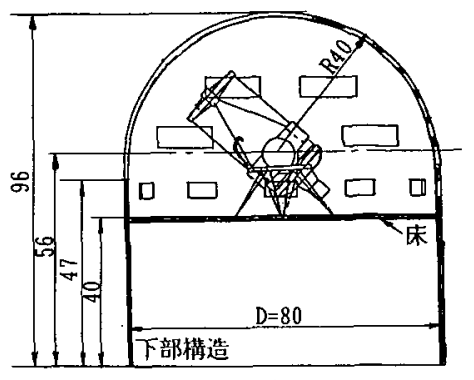

(a) 半球形ドーム

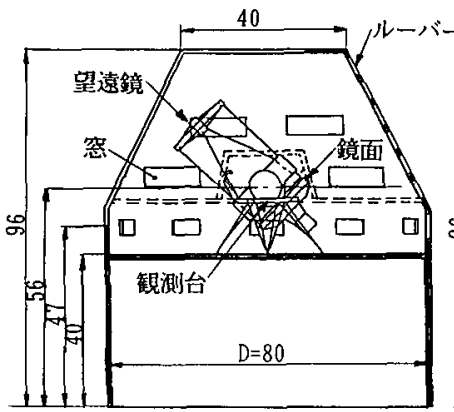

(b) 台形ドーム

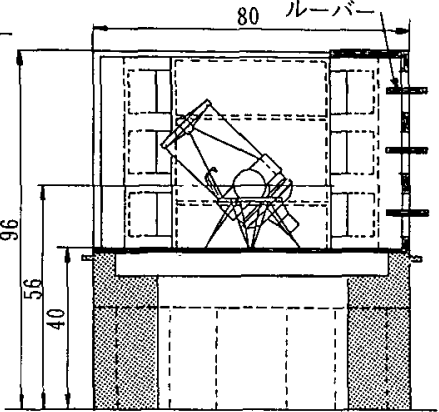

(c) 円筒形ドーム

図1ドーム模型

るため、スリットを主たる流路と考え流入速度を減ず るための金湅あるいは多孔板をもうけ、また外部流線 を制御するための整流板をスリットの下部に設けた。 半球形は従来からの形状であり、台形は流体的に考虑 されたもので仏国が南米チリに建設した実績があり(3) 円筒形はこれらと発想を変えたものである。模型は可 視化に都合の良い樣に全て透明アクリル材を用い、内 部流の観察のために 3 点に色素注入管を設け、フラッ シング時間(flushing time) 即ち内部の流体を流入し た外部流にとって変る時間を测定するための色素の注 入れとしても用いた。
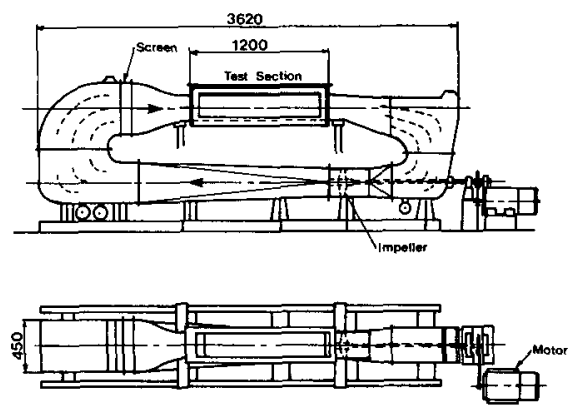

図2 垂值循猿式小型回流水槽

実験に使用した垂直毄環型小型回流水槽 (4)を図 2 に示す。試験部は長さ $1,200 \mathrm{~mm}$ 、幅・水深之 も200mmである。流速は $5 \sim 150 \mathrm{~cm} / \mathrm{s}$ の範囲で可変である。

\section{3. 実験方法}

風速に対応する一様流の流速U。は、観察の容易さとレイノルズ数特性に対する考虑から10 25 $\mathrm{cm} / \mathrm{sec}$ を選んだ。 $\mathrm{U}_{\mathrm{o}}=25 \mathrm{~cm} / \mathrm{sec}$ の時の円柱径レイノルズ数は $\mathrm{Re}_{\mathrm{D}}=\mathrm{U}_{\mathrm{o}} \cdot \mathrm{D} /$ レ $=2.28 \times 10^{4}$ である。地 表附近流に相当する流れの流入高さは上流に設監した線径 $0.08 \mathrm{~mm}$ ステンレスキンク線を用いた水 素気泡法によって可視化された流脈から求め、ドーム内外部の流れバターンはローダミンB、メ チレンブルー及びフルオレセインを用いた色素流脈法により可視化して観察した。またフラッシ ング特性は、ドーム床中心の吹出孔から瞬間的に色素を注入して内部を充填し、これが洗い流さ れるまでの時間として测定した。映像記録は上方及び側方に設置した TVカメラにより撮影し、 V T Rに記録した。記録した画像は画像静止装置によって静止画像とし、特に流入高さの测定で 


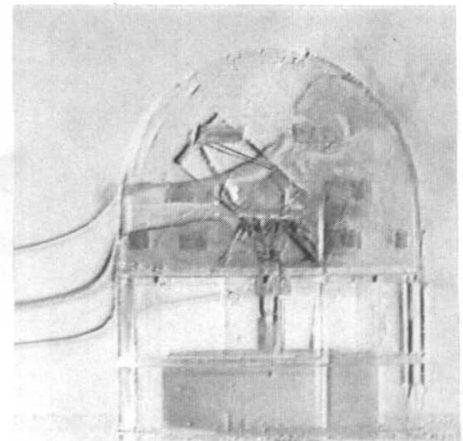

(a) 半球形ドーム

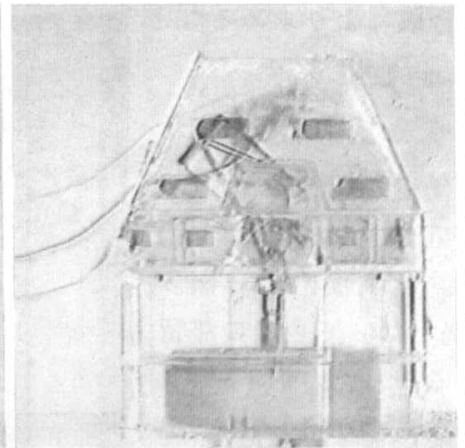

(b) 台形ドーム

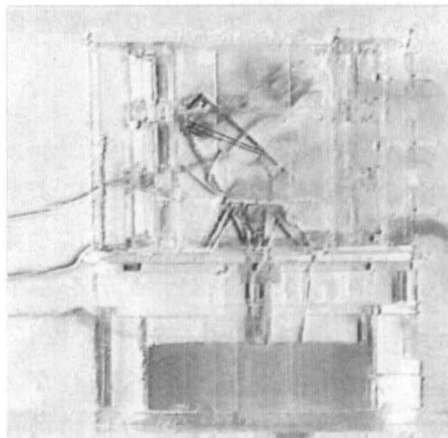

(c) 円筒形ドーム

図3 色素流脈法による内部流れの可視化
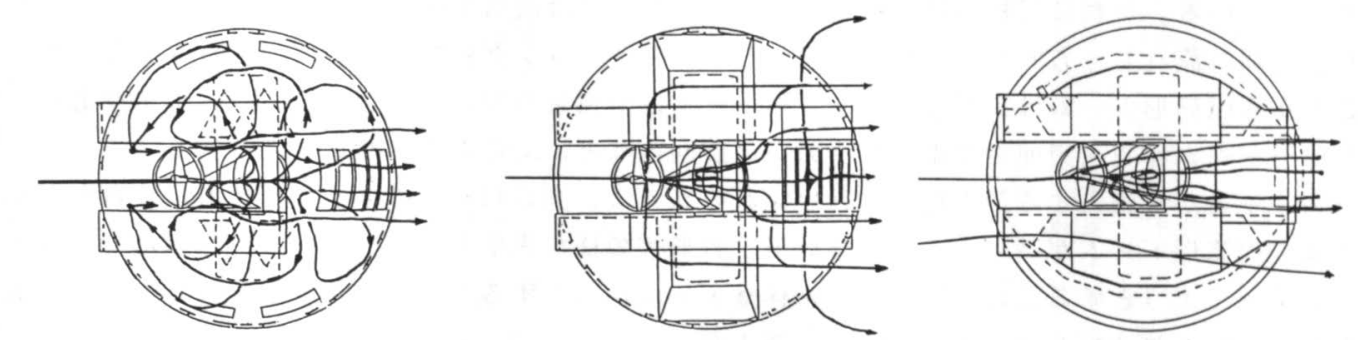

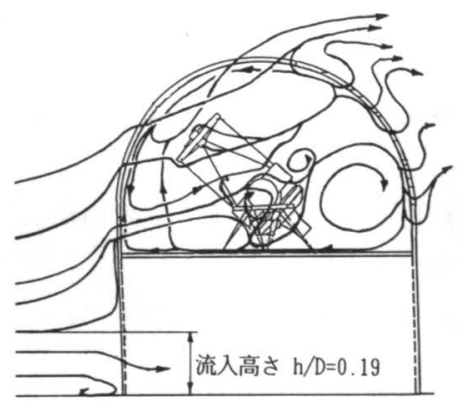

(a) 半球形ドーム

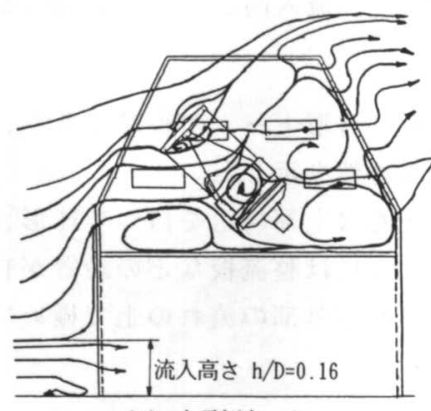

(b) 台形ドーム

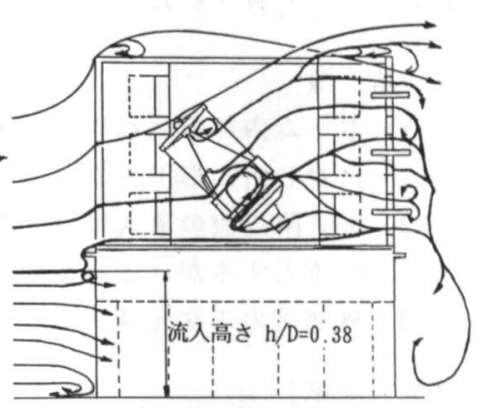

(c) 円筒形ドーム

図4 各ドームの流れバターンのスケッチ

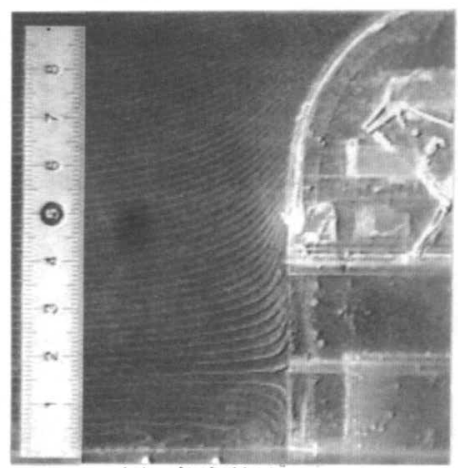

(a) 半球形ドーム

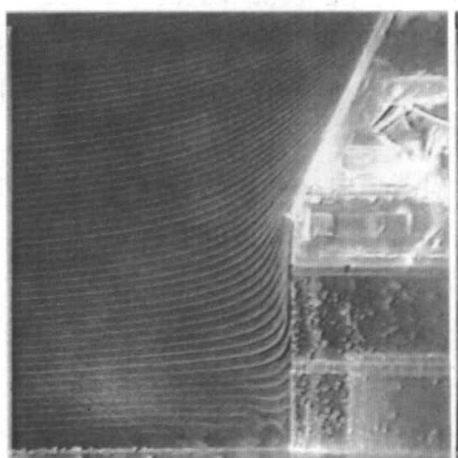

(b) 台形ドーム

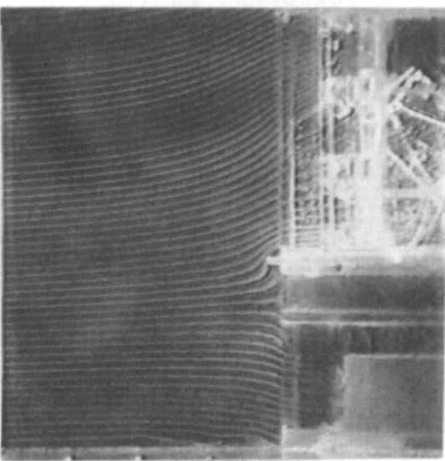

(c) 円筒形ドーム

図5 水素気泡法による流入高さの可視化 
は予め撮影したスケール画像との合成により求めるなど の処理を行った。

\section{4. 実験結果}

図 3(aｃ) に色素流脈法による代表的な内部流れの可 視化像を示し、図 $4(\mathrm{a} \sim \mathrm{c})$ に水素気泡法の結果と合せて 描いた流れ模様のスケッチを示す。半球形ドーム(図 3 (a)、4(a))では望遠鏡の前後に渦となって色素の滞留 が見られ床面で旋回する流れがある。また台形ドーム (図 3 (b)、4 (b)) でも望遠鏡の前後に渦があり、きれい に流れ出ていない。これに対し円筒形ドーム(図 $3($ c)、 4 (c))では望遠鏡による拡散は多少残るが概ねきれいに

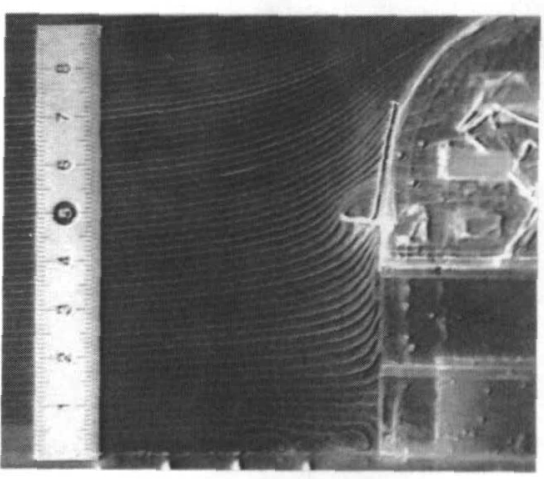

図6 整流板の効果 (半球形ドーム) 流れ出ている。これは円柱形状の样な二次元的な構造では流れ全体が地面に平行になる傾向を有 し、内部の流れも一方向に向うためと思われる。フラッシング特性は、内部に大きな滞留が無い ことから円筒形ドームは良好であり、台形ドームは望遠鏡前後の渦による滞留のためやや劣り、 半球形ドームは望遠鏡前後の渦と水平方向の旋回流などによる滞留の残存により劣る。

スリットから流入する最も地表に近い流れの高さは、図 $5(\mathrm{a} \sim \mathrm{c})$ のように半球形及び台形ドー ムより円筒形ドームが高い。これは半球形、台形等の椂な先細りの三次元的な上部構造ではドー 厶を乗越えようとする流れが強くこれに伴う上昇流が存在することによる。また図 6 の樣に半球 形ドームでも整流板を設けることにより流入高さの改善が四れる。

\section{5. 結 論}

（1）ドーム内部の流れは、半球形、台形ドームが複雑であり、フラッシング特性も悪く、これ に対し円筒形ドームが良好な特性を示した。

（2）地表附近流の流入は、三次元的な上部構造を持っ半球形、台形ドームほど低い位置の流れ が流入するが、これを抑制するには整流板などの設置が有効である。

(3) 外部流の二次元性がドーム内及び外部の流れの上で極めて重要であることが分かった。

\section{[参考文献]}

（1）国立天文台、「大型光学赤外線望遠鏡計画説明書」、1989年9月

(2) L.Barr, H.Ando, A.Miyashita, K.Sakata, S.Shindo, "Some Air Flow Properties of Telescope Enclosures Estimation from Water Tunnel Tests", Pub. of the Astronomical Soc. of the Pac., June. 1991

（3）坂田他、「タービン翼フィルム冷却流の水流模型による可視化小、流れの可視化、Vo1.4, No. 14、1984年7月

(4) Siriluk Limmongko1, et a1., "Flow Visualization of Telescope Enclosure Mode1s.", AIAA Reg. 4 Stud. Conf., Apri1 25-28,1990 